\title{
Veloplastia funcional secundaria: Una alternativa no obstructiva en el tratamiento de la insuficiencia velofaríngea
}

\author{
Secondary functional veloplasty: a non-obstructive approach to \\ valopharyngeal insufficiency
}

J. Cortés Araya ${ }^{1,2}$, A.Y. Niño Duarte3 , H.H. Sung Hsieh, B. Gómez Sánchez ${ }^{5}$

Resumen: Introducción. La insuficiencia velofaríngea es quizá la secuela más común de las técnicas de veloplastia realizadas para la corrección de las fisuras palatinas. A menudo la terapia fonoaudiológica se encuentra limitada, obteniéndose generalmente sólo resultados parciales.

En estos casos la faringoplastia se presenta como el tratamiento de elección, existiendo diversas técnicas publicadas. Éstas, cualesquiera que sean, tienen en común la utilización de colgajos faríngeos que determinan una reducción del diámetro de la vía aérea superior con el consiguiente riesgo de generar un trastorno obstructivo del sueño. Objetivos. En el ánimo de obviar esta situación y simultáneamente alargar y dar competencia velopalatina, se ha diseñado una técnica quirúrgica que tiene por objetivo la reconstrucción morfofuncional velar o veloplastia funcional secundaria, inspirada en los principios de Delaire.

Material y técnica quirúrgica. Presentamos nuestra experiencia basada en una serie de 15 casos tratados de esta nueva manera: se divide completamente el paladar blando, incindiendo sobre la línea media y exponiendo ambos hemivelos hasta la región retrouvular. En ese momento se busca e identifican las estructuras musculares remanentes, se separan del borde óseo palatino y de las mucosa nasal y bucal y se unen en una posición más posterior con las contralaterales en la línea media.

Resultados. En nuestra experiencia se ha logrado el alargamiento velopalatino y la corrección o mejoramiento de rinolalias. En la evaluación de resultados hemos utilizado tanto el examen clínico fonoaudiológico como la aerofonoscopía con muy buenos resultados comparativos.

Palabras clave: Insuficiencia Velofaríngea; Incompetencia Velofaríngea; Palatoplastia.

\begin{abstract}
Introduction: Velopharyngeal insufficiency could be produced by a partial or inappropriate veloplasty performed to correct palate clefts. Phonoaudiologic therapy is often limited, and generally only obtains partial results. In these cases, pharyngoplasty seems to be the procedure of choice, there being several techniques published. Whatever they are, they have the common factor of the use of pharyngeal flaps that determine a reduction of the upper airway diameter with the consequent risk of generating obstructive sleep disorder. Objective: In order to obviate this situation and simultaneously lengthen and provide velopalatine competence, a surgical technique, inspired by the DELAIRE principles, that aims to make the velar mophofunctional reconstruction or secondary functional veloplasty has been designed. Surgical procedure: We present our experience based on a series of 15 cases treated in this new way: the soft palate, affecting the middle line and exposing both hemivelar portions until the retrouvular region. At this moment, the remaining muscular structures are identifyed, the palatal bone and nasal and buccal mucosa border are separated and are joined in a more posterior position of the contralaterals of the midline. Results: In our experience, we have achieved velar lengthening and hypernasal correction or improvement. After the surgery, patients were evaluated with a phonetic test and aerophonoscopy. The outcome of this evaluation has shown the effectiveness of this surgical technique.
\end{abstract}

Keywords: Velopharyngeal Insufficiency, Velopharyngeal Incompetence, Palatoplasty

\footnotetext{
1 Profesor Asociado de Cirugía Máxilofacial,

Facultad de Odontología, Universidad de Chile, Chile.

2 Cirujano de la Unidad de Fisurados, Hospital Dr. Félix Bulnes Cerda. Santiago de Chile, Chile.

3 Cirujana Máxilofacial, Venezuela.

4 Instructora ad-honorem, Facultad de Odontología, Universidad de Chile, Chile.

5 Fonoaudiólogo, Facultad de Odontología, Universidad de Chile, Chile.
} 


\section{Introducción}

Es común observar la presencia de secuelas, en pacientes nacidos con fisuras velares o velomaxilares, que han recibido como tratamiento primario veloplastias (Fig. 1). Estas secuelas se expresan como disfunciones velares, afectando a la voz y a la audición de los pacientes que la sufren. Clínicamente las reconocemos como rinolalias abiertas al afectar a la voz, nasalizándola y por otro lado encontramos hipoacusias, secundarias a otitis medias crónicas, al afectar la ventilación del oído medio.

Los trastornos originados por la disfunción velar son agrupados bajo el término de «Insuficiencias Velofaríngeas». Definimos la insuficiencia velofaríngea como la incapacidad de oclusión del esfínter velofaríngeo, permitiendo el escape del aire hacia la cavidad nasal durante la emisión de fonemas, vocálicos y consonánticos, excepto

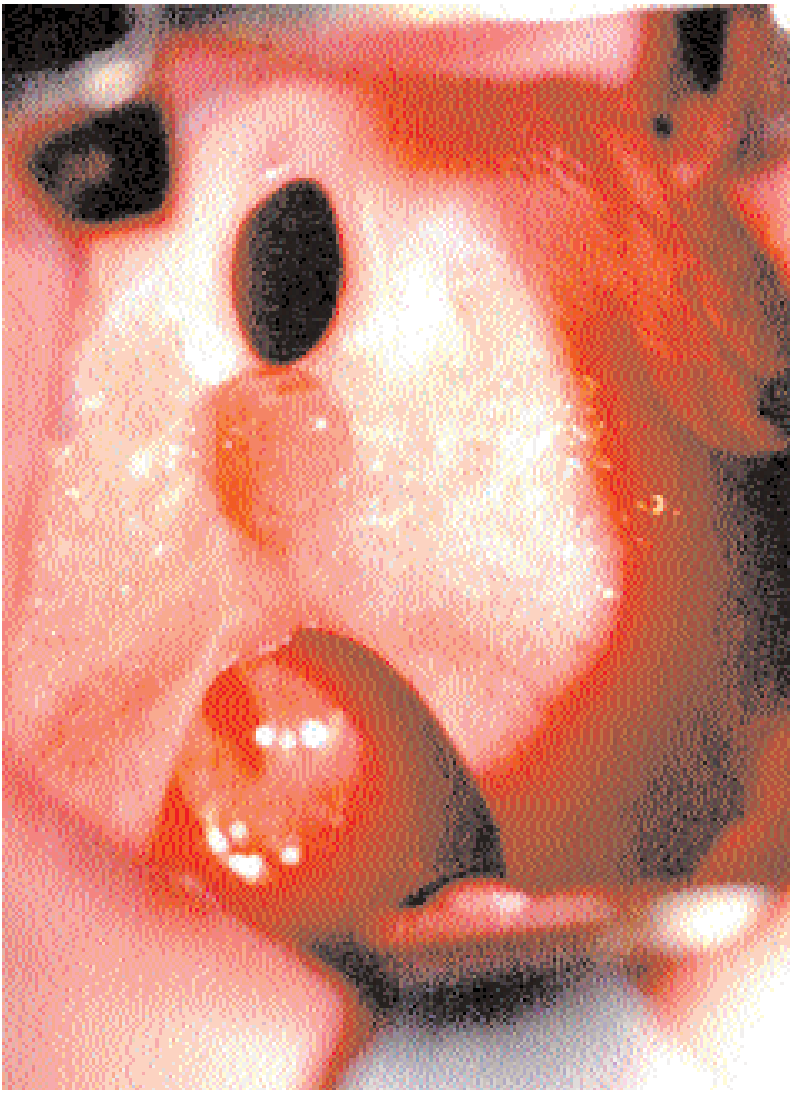

Figura 1. Insuficiencia velofaríngea severa. Figure 1. Severe velopharyngeal insufficiency.

\section{Introduction}

It is common to observe the presence of sequels in patients born with velar or velomaxillary clefts, who have received veloplasties as primary treatment (Fig. 1). These sequels are expressed as velar dysfunctions, affecting the voice and audition of the patients suffering it. Clinically, they are known as open rhinolalia as the voice is affected, it becoming nasal, and on the other hand, we find hypoacusis, secondary to chronic otitis media, that affects middle ear ventilation.

The disorders caused by velar dysfunction are grouped under the term of "Velopharyngeal insufficiencies." We define velopharyngeal insufficiency as the incapacity of occlusion of the velopharyngeal sphincter, permitting the air to escape towards the nasal cavity during the emission of vocalic and consonant phonomes, except for $m, n$ and $\tilde{n}$ which are, by nature, nasal. In these cases, the velum is, to a greater or lesser degree, shortened, atrophic and its muscular fibers are displaced from their normal insertion site, and are incapable of moving in para $m$, $n$ y ñ que son por naturaleza nasales. El velo en estos casos se encuentra en mayor o menor medida, acortado, atrófico y con sus fibras musculares desplazadas de su sitio normal de inserción, siendo incapaz de movilizarse hasta contactar la pared faríngea como normalmente ocurre. Generalmente en estos casos la terapia fonoaudiológica se encuentra limitada y sus resultados son a menudo insatisfactorios.

La faringoplastia se presenta clásicamente como el procedimiento de elección en estos casos, existiendo numerosas técnicas descritas (Fig. 2). ${ }^{1}$ Estos procedimientos, cualesquiera que sean, tienen por objetivo desplazar la mucosa y el velo del paladar hacia atrás, en un llamado desplazamiento palatino posterior o Push back, que acerca el borde posterior del velo a la pared faríngea, para suturarla luego a un colgajo que se talla en la pared posterior de ésta, ya sea con base superior o inferior. El resultado es que efectivamente se logra impedir el escape de aire hacia las fosas nasales, mejorando la rinoIalia pero con el costo biológico de una reducción en el diámetro de la vía aérea superior con el consiguiente menoscabo respiratorio. Diversos estudios demuestran que este deterioro en la capacidad respiratoria afecta más gravemente a los niños que a los adultos. ${ }^{2}$ Hoy sabemos que una reducción de la vía aérea superior no sólo significa transformar en roncador a un paciente que no lo era previamente al acto quirúrgico, sino que se corre el riesgo de generar un trastorno obstructivo del sueño que derive en una alteración grave del ritmo circadiano, que se exprese por ejemplo en un S.A.R.V.A.S. (Síndrome de Aumento de la Resistencia de la Vía Aérea Superior $)^{3}$ o order to contact with the pharyngeal wall as normally occurs. Generally, in these cases, the phonoaudiological therapy is limited and its results are often unsatisfactory.

The pharyngoplasty classically presents as the procedure of choice in these cases, many techniques having been described (Fig. 2).? These procedures, whatever they are, aim to displace the mucosa and soft palate backwards, in a socalled posterior palate displacement or push back, that approaches the posterior border of the velum to the pharyngeal wall. It is then sutured to a flap that is cut in its posterior wall, either with the superior or inferior base. The result is that, in fact, air escape toward the nasal pits can be prevented, improving the rhinolalia but with the biological cost of a reducrespiratory reduction. Several studies show that this deterioration in respiratory capacity affects children more seriously than adults. ${ }^{2}$ We presently know that a reduction in the upper airway not only means converting a patient who did not snore before the surgical act into one who does but also running the risk of generating a sleep obstructive disorder that produces a serious circadian rhythm alteration that is expressed, for example, in an I.U.A.R.S. (Increased Upper Airway Resistance Syndrome) ${ }^{3}$ or in a S.A.S. (Sleep Apnea Syndrome).

Based on our preliminary experience of 15 cases, this article aims to present an original surgical treatment that tion in the diameter of the upper airway with the consequent 
en un S.A.S. (Síndrome de Apnea del Sueño).

El objetivo de este artículo es presentar, basados en nuestra experiencia preliminar de 15 casos, un tratamiento quirúrgico original que corrige la insuficiencia velofaríngea sin afectar el diámetro de la Vía Aérea Superior, consiguiendo una morfología velar apropiada, permitiendo subsecuentemente la emisión de una voz y una audición adecuadas.

\section{Material y método}

Desde enero de 2000 hasta junio de 2002 hemos tratado una serie de quince casos de pacientes portadores de secuelas de fisuras velares, caracterizadas por insuficiencia velofaríngea moderada o severa, fisuras o fístulas buconasales residuales y bridas por cicatriz mucosa. Estos pacientes tenían al momento de la cirugía un rango de edad entre 8 años y 22 años y todos fueron evaluados, previo al tratamiento quirúrgico, por el mismo fonoaudiólogo, tomándose luego la decisión quirúrgica en conjunto entre el fonoaudiólogo y el cirujano.

Con fines prácticos, hemos clasificado las insuficiencias velofaríngeas en tres tipos: leve, que corregimos en base a reeducación fonoaudiológica; moderada y severa que tratamos con reeducación fonoaudiológica y reconstrucción quirúrgica.

En la decisión de efectuar o no este procedimiento quirúrgico, hemos definido Criterios de Inclusión, considerando aquellos pacientes que a pesar del acortamiento velar, posean un tejido mus-

cular velar morfológicamente adecuado y como Criterios de Exclusión, aquellos pacientes con reparaciones musculares previas marcadamente asimétricas o en los que se compruebe pérdidas tisulares severas o bien, alguna discapacidad o alteración de orden neurológico.

Se ha diseñado una técnica quirúrgica que tiene por objetivo la reconstrucción anatómica del velo del paladar en base a los elementos musculares disponibles y que puedan ser identificados, disecados y recuperados funcionalmente. ${ }^{4}$ Esta técnica permite recuperar simultáneamente la competencia velofaríngea, -mejorando las condiciones morfológicas y funcionales del velo del paladar-, suprimir la rinolalia e intenta conseguir un mejoramiento en la ventilación del oído medio.
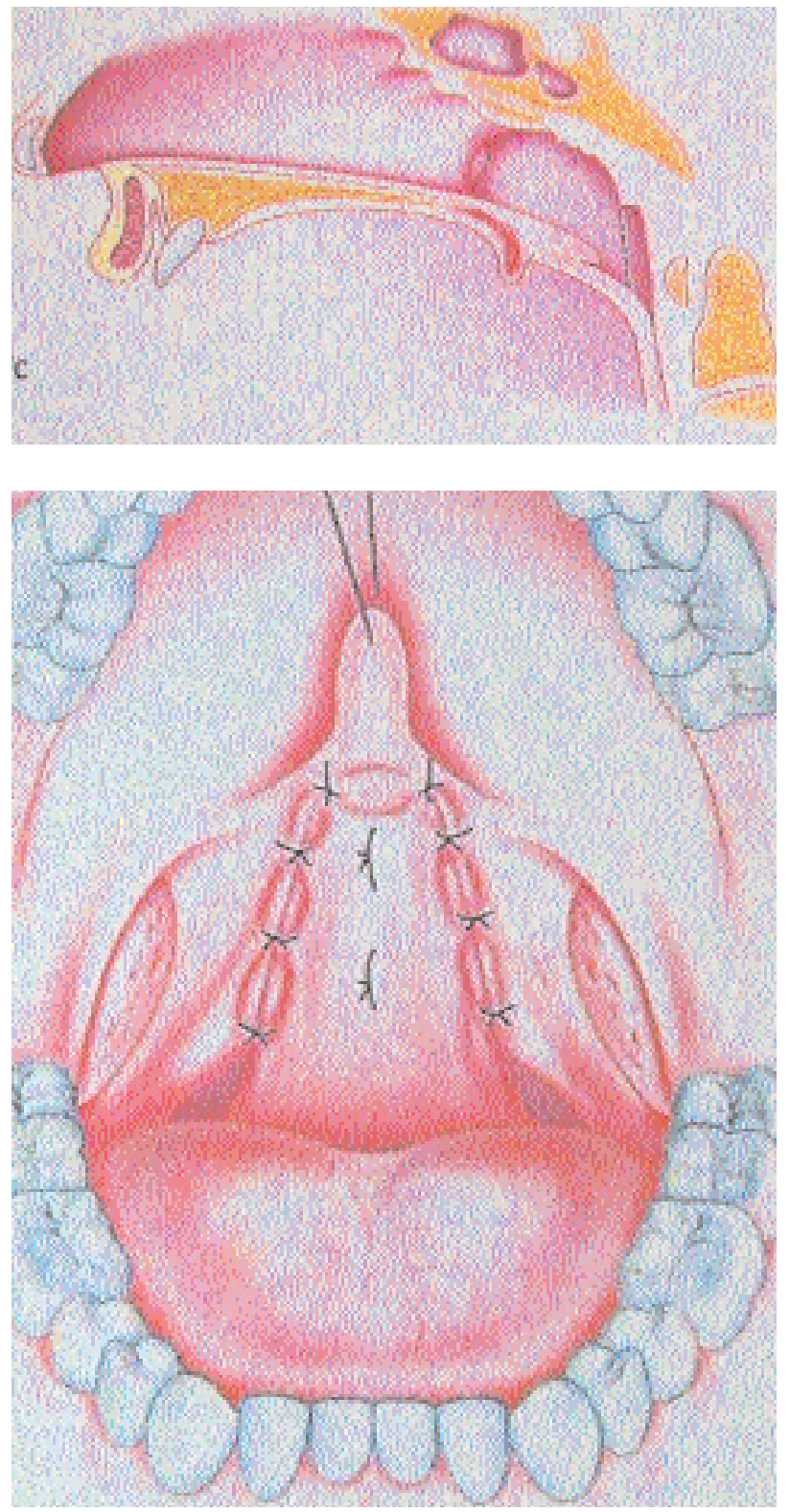

Figura 2. Faringoplastia de base inferior. A) Vista lateral. B) Vista frontal. Tomado de MERCIER en Enciclopedia Médica Quirúrgica. Figure 2. A) Lateral view. B) Frontal view. Lower base pharyngoplasty. Taken from MERCIER in the Enciclopedia Médica Quirúrgica. corrects velopharyngeal insufficiency without affecting the upper airway diameter and achieving an appropriate velar morphology, that subsequently permits the emission of adequate voice and audition.

\section{Material and method}

From January 2000 to June 2002 , we treated a series of 15 cases of patients having velar cleft sequels, characterized by moderate or severe velopharyngeal insufficiency, residual bucconasal clefts or fistulas and adherences due to mucosa scaring. At the time of surgery, the patients were between 8 and 22 years of age and all were evaluated, prior to the surgical treatment by the same phonoaudiologists, the surgical decision being made jointly by the phonoaudiologist and the surgeon.

For practical reasons, we have classified velopharyngeal insufficiencies into three types: mild, that we correct based on phonoaudiological reeducation; moderate and severe that we treat with phonoaudiological reeducation and surgical reconstruction. In the decision to perform this surgical procedure or not, we have defined Inclusion Criteria, considering those patients who, in spite of velar shortening, have a morphologically adequate velar muscular tissue and as Exclusion Criteria, those patients with previous marked asymmetric muscular reparations or in whom severe tissue loss is verified or in whom there is some neurological incapacity or alteration.

A surgical technique has been designed that aims to make the anatomical reconstruction of the soft palate based on the muscular elements available and that can be identified, dissected and functionally recovered. ${ }^{4}$ This technique makes it possible to simultaneously recover velopharyngeal competence, improving the morphological and functional conditions of the soft palate, eliminating rhinolalia and 
El procedimiento se fundamenta en la comprobación empírica que en muchas incompetencias velofaríngeas existe un sustrato anatómico disponible que, si bien no funciona adecuadamente ya que los músculos están a menudo desplazados, atróficos y deformados, es posible rescatar y reestablecer su funcionalidad. Esta operación constituye entonces una reconstrucción funcional secundaria del velo del paladar o veloplastia funcional secundaria, inspirada en los principios funcionales de Delaire. ${ }^{5}$ Los pacientes fueron estudiados con registros aerofonoscópicos practicados previos a la reparación quirúrgica y posterior a ella.

El objetivo quirúrgico es identificar, disecar y reinsertar adecuadamente los tejidos. Con la ayuda de un abrebocas que nos permite disponer de un campo operatorio adecuado, debemos en primer término realizar una apertura total del paladar seccionándolo sagitalmente en la línea media. Para exponer completamente la región, incidimos desde la región retrouvular, a la altura donde deberían encontrarse los pilares posteriores por atrás, hasta la mucosa que recubre el paladar duro por delante, buscando la referencia ósea de la espina nasal posterior. De esa manera exponemos ambos hemivelos, quedando los bordes cruentos hacia la línea media. Hecho ésto tenemos acceso suficiente para disecar desde la bóveda del paladar hasta la región de los pilares posteriores (Figs. 3 y 4). En este momento disecamos el plano muscular, buscando el músculo periestafilino externo o músculo tensor del velo y el músculo periestafilino interno o músculo elevador del velo que deben ser desinsertados del paladar óseo y llevados hacia atrás, para luego ser unidos en la línea media. Con el pilar posterior o músculo faringoestafilino de cada lado hacemos lo mismo, lo disecamos para unir uno con el contralateral y establecer así una disposición tal entre ellos que sea la más parecida a la anatomía normal. Ponemos especial énfasis en la preservación de los ganchos pterigoideos y de sus inserciones musculares (Figs. 5 y 6), ya que éstos resultan capitales para la preservación de la función tensora junto a la elevadora del velo del paladar.

A continuación se identifica la mucosa de la cara nasal del paladar duro y se procede a suturarla con su contralateral, estable-

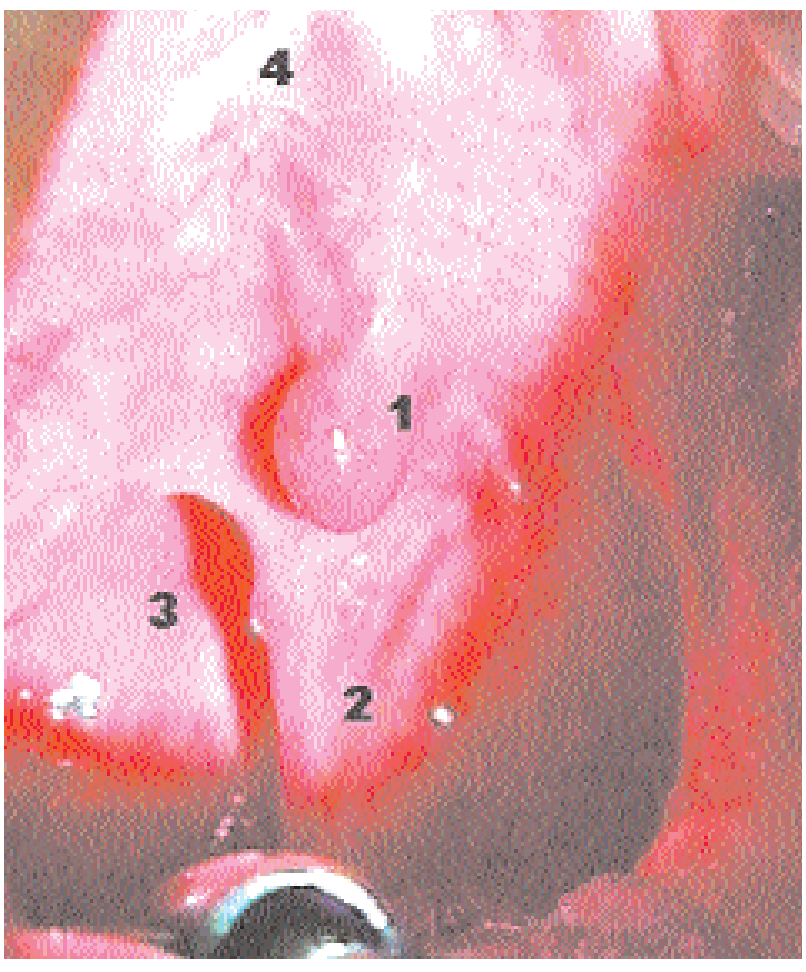

Figura 3. Preoperatorio. Insuficiencia velofaríngea. 1) Úvula lateralizada. 2) Pilar posterior. 3) Pared faríngea. 4) Aponeurosis palatina.

Figure 3. Pre-operative. 1) Lateralized uvula. 2) Posterior pillar. 3) Pharyngeal wall. 4) Palatine aponeurosis.

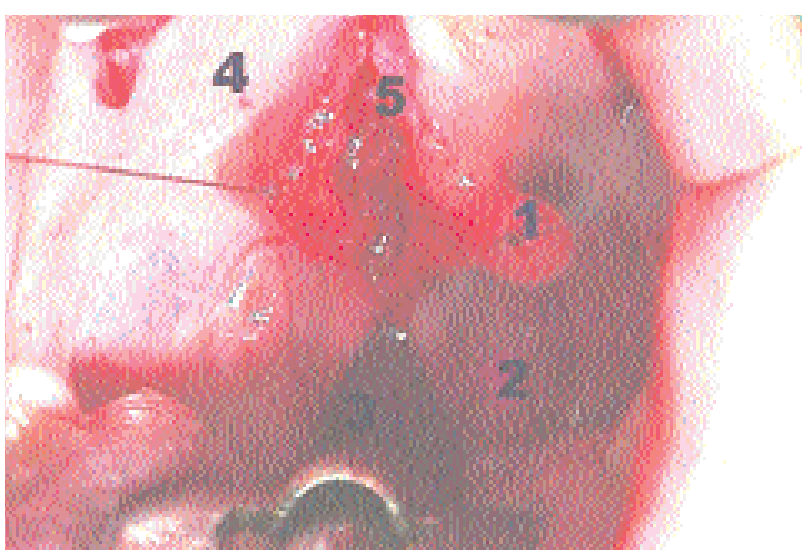

Figura 4. Recunstrucción muscular. Insuficiencia velofaríngea. 1) Úvula lateralizada. 2) Pilar posterior. 3) Pared faríngea. 4) Aponeurosis palatina. 5) Piso nasal ya cerrado.

Figure 4. Muscular reconstruction. Velopharyngeal insufficiency. 1) Lateralized uvula. 2) Posterior pillar. 3) Pharyngeal wall. 4) Palatine aponeurosis. 5) Already closed nasal floor. trying to achieve improvement in middle ear ventilation.

The procedure is based on the empiric verification that there is an anatomic substrate available in many velopharyngeal incompetences, whose functionality can be rescued and reestablished although it does not function adequately since the muscles are often displaced, atrophic and deformed. Thus, this operation is a secondary functional reconstruction of the soft palete or secondary functional veloplasty, inspired by the functional principles of Delaire. ${ }^{5}$ The patients were studied with aerophonoscopic registries performed prior to and after the surgical repair.

The surgical objective is to identify, dissect and adequately reinsert the tissues. With the help of a mouth opener that allows us to have an adequate operative field, we should first perform a total opening of the palate, sectioning it sagitally in the middle line. To completely expose the region, we incise from the retrouvular region at the height in which the posterior pillars should be found behind until the mucosa that lines the hard palate in front, searching for the bone reference of the posterior nasal spine. In this way, we expose both hemivelums, the borders remaining reverted towards the middle line. Once this is done, we have sufficient access to dissect from the palate vault to the region of the posterior pillars (Figs. 3 and 4). At this time, we dissect the muscular plane, searching for the elevator muscle of the soft palate or elevator muscle of the velum that should be uninserted from the bone palate and carried backwards, to then be joined in the middle line. 
ciéndose así una separación neta entre ambas cavidades, nasal y bucal. Se prosigue suturando, desde delante hacia atrás, llevando así la musculatura del paladar blando previamente disecada a una posición más posterior a la que previamente tenía. Se completa el ciere de este plano muscular con la reconstrucción de los pilares posteriores, que se buscan por detrás de la región de la úvula. Una vez cerrado este plano nasal y muscular -funcional- se procede a cerrar el plano bucal. Se inicia cerrando la cara inferior de los pilares posteriores, la úvula, la zona del paladar blando propiamente tal hasta llegar a la zona del paladar duro. En este momento se corrigen las eventuales fístulas o se eliminan las bridas o pliegues que existan.

Para la evaluación de los resultados se practicó en cada paciente un examen fonoaudiológico. Este examen fue realizado en todos los casos por el mismo especialista. Con la finalidad de objetivar el estudio de los resultados, éste incluyó una evaluación instrumental hecha por medio de un aerofonoscopio. Tanto esta evaluación como el examen fonoaudiológico fueron practicados tanto en el preoperatorio como en el período postoperatorio de cada paciente. Los estudios aerofonoscópicos se realizaron con un aparato y operado en todos los casos por el mismo fonoaudiólogo.

\section{Resultados}

En las figuras de la 7 a la 12 se observan los registros aerofonoscópicos referidos a los fonemas «CHI - LLA», «l», «U», e «l» prolongada, pretratamiento y postquirúrgicos del caso ilustrado.

En la mitad superior de los gráficos se aprecia el escape indebido de aire a través de la nariz por fallo en la oclusión del esfínter velar y en la mitad inferior la intensidad en la emisión del fonema. Podemos comprobar como después de la corrección quirúrgica, el escape de aire se hace casi imperceptible y la intensidad de la voz aumenta considerablemente.

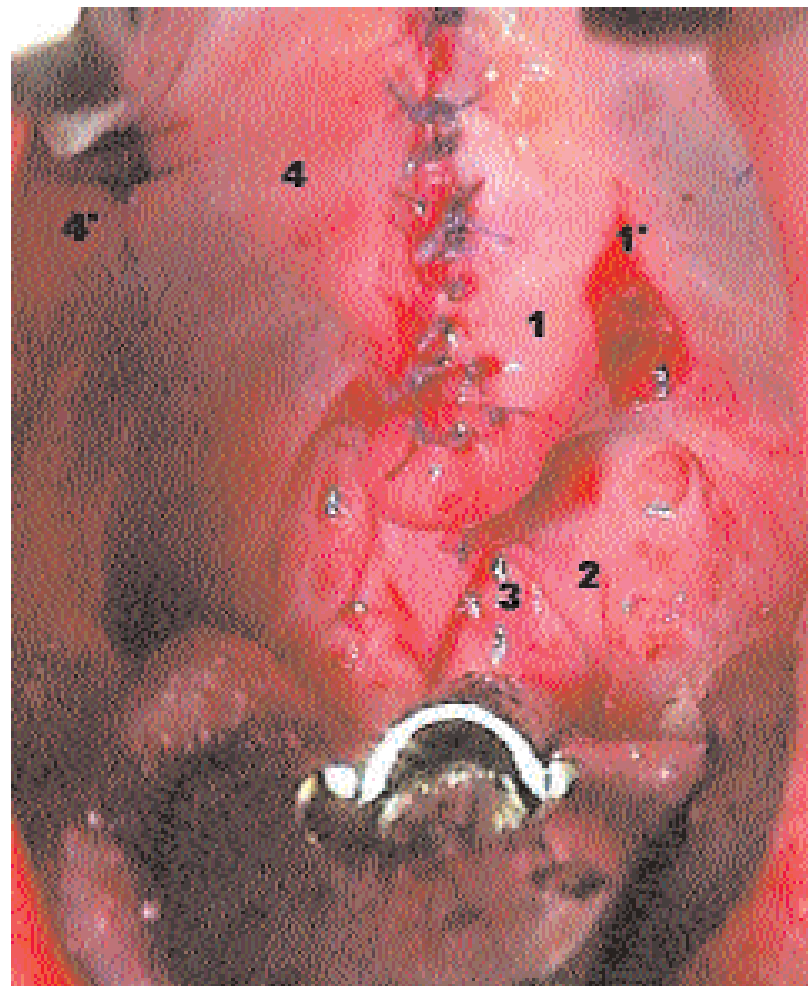

Figura 5. Postoperatorio inmediato. 1) Úvula recontruida. 1') Incisión parauvular de descarga. 2) Pilar posterior. 3) Pared faríngea. 4) Aponeurosis palatina. 4') Incisión de descarga.

Figura 5. Immediate post-operative. 1) Reconstructed uvula 1') Parauvular release incision. 2) Posterior pillar. 3) Pharyngeal wall. 4) Palaine aponeurosis. 4') Release incision.

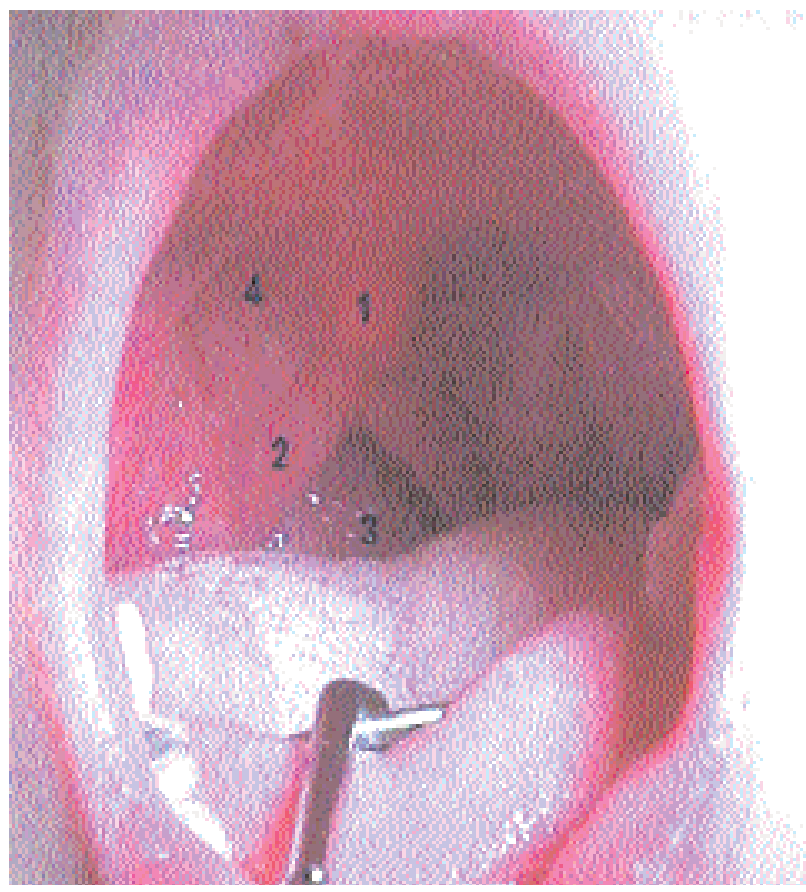

Figura 6. Postoperatorio tardío. 1) Úvula recontruida. 2) Pilar posterior. 3) Pared faríngea. 4) Aponeurosis palatina.

Figura 6. Late post-operative. 1) Reconstructed uvula 2) Posterior pillar. 3) Pharyngeal wall. 4) Palaine aponeurosis.
We do the same with the posterior pillar or palatopharyngeal muscle of each side. We dissect it to join one with the contralateral side and thus establish an arrangement between them that is as similar as possible to normal anatomy. We place special emphasis on the preservation of the pterygoid hooks and of their muscular insertions (Figs. 5 and 6), since they are important for the preservation of the tensor function together with the elevator of the soft palate.

Then the mucosa of the nasal side of the hard palate is identified and sutured with its contralateral side, thus establishing a clear separation between the nasal and buccal cavities. Suturing is continued, from front to back, thus moving the previously dissected soft palate musculature to a more posterior position than it previously had. The closure of this muscular plane is complet$e d$ with the reconstruction of the posterior pillars, that are searched for behind the uvula region. Once this nasal and muscular (functional) plane is closed, the buccal plane is closed. It is started by closing the inferior side of the posterior pillars, the uvula, the soft palate area itself until reaching the hard palate area. At this time, the possible fistulas are corrected or the adherences or folds existing are eliminated.

A phonoaudiological examination was performed in each patient to evaluate the results. This examination was performed by the same specialist in all the cases. In order to make the study of the results objective, the examination included an 


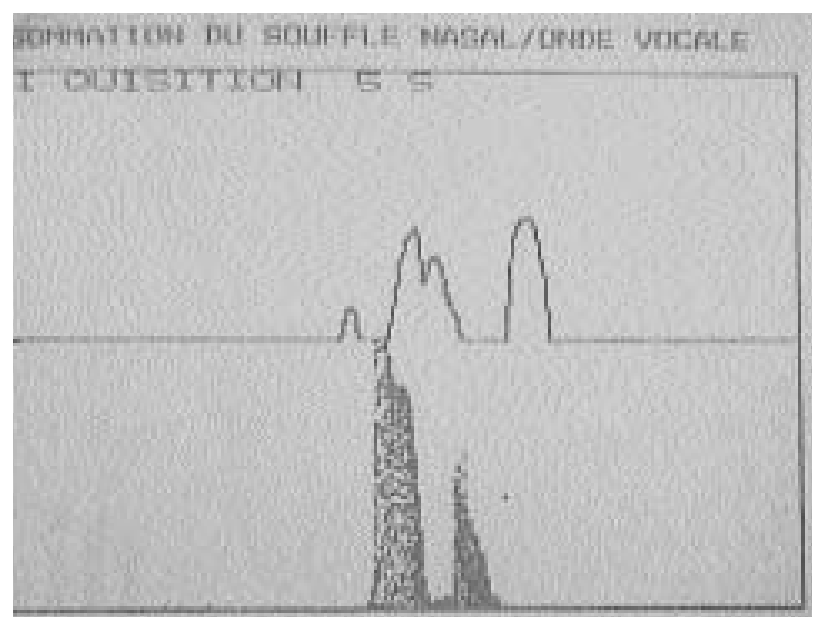

Figura 7. Registro preoperatorio. Gran escape de aire por la nariz con intensidad adecuada de la voz. (Fonema: «CHI-LLA»).

Figure 7. Pre-operative registry. Large air exape through the rose with adequate voice incision. Phonema "CHI-LLA").

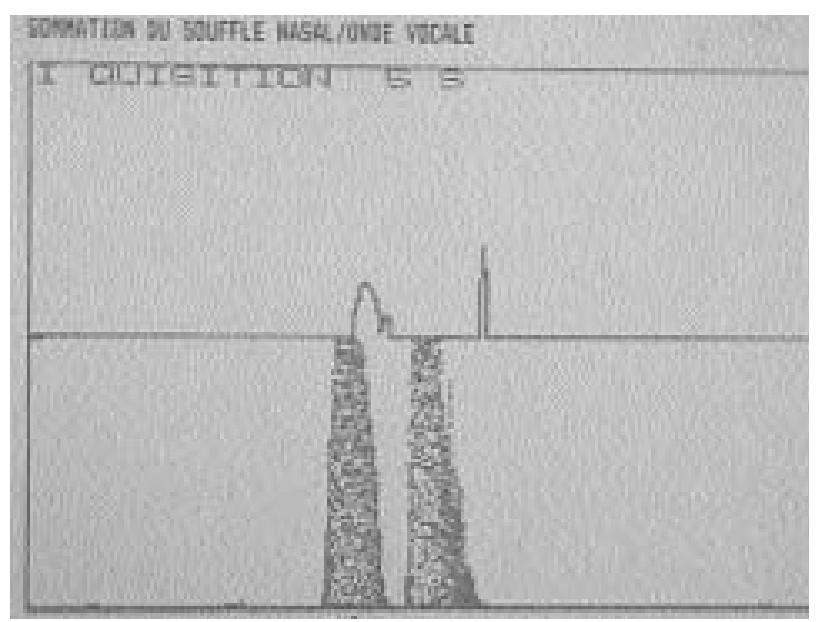

Figura 9. Registro preoperatorio. Gran escape de aire por la nariz y débil intensidad de la voz. (Fonemas: «I-U»).

Figure 9. Pre-operative registry. Large air escape though the nose and weak voice intensity. Phonemas: "I-U".

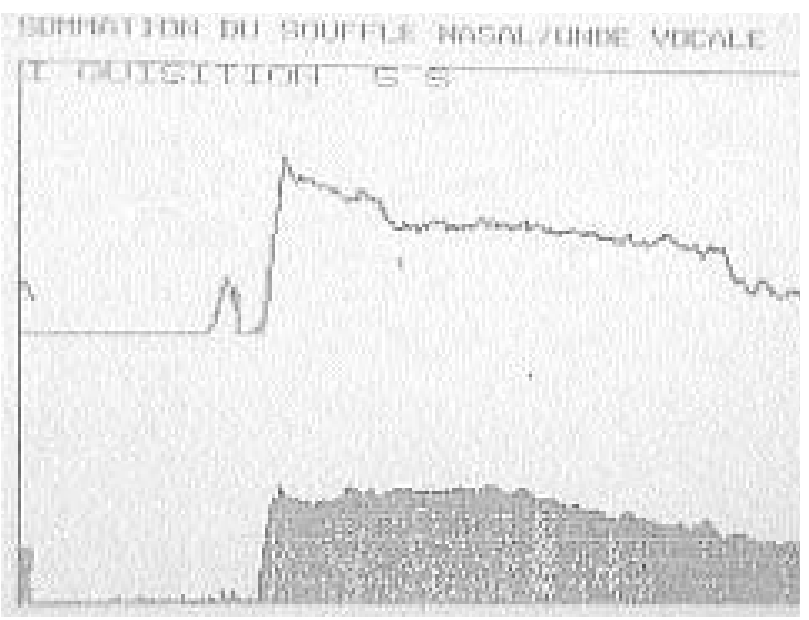

Figura 11. Registro preoperatorio. Débil intensidad de la voz. (Fonema: «IIIIIIII» vocal prolongada).

Figure 11. Pre-operative registry. Weak voice intensity. Phonema: "IIIIIII" (prolonged vowel).

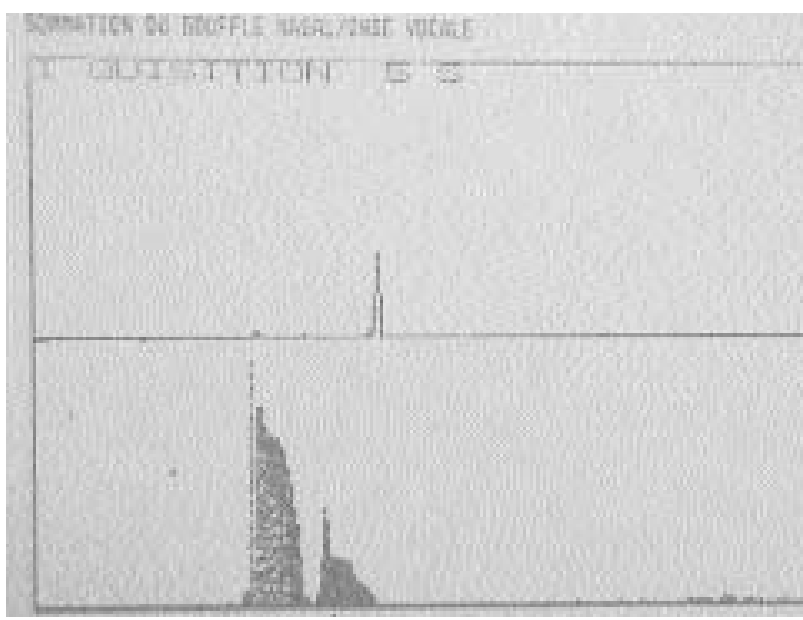

Figura 8. Registro preoperatorio. Disminución del escape de aire y mantención de la intensidad de la voz. (Fonema: «CHI-LLA»). Figure 8. Post-operative registry. Decrease in air escape and maintenance of voice intensity. Phonema "(HI-LLA").

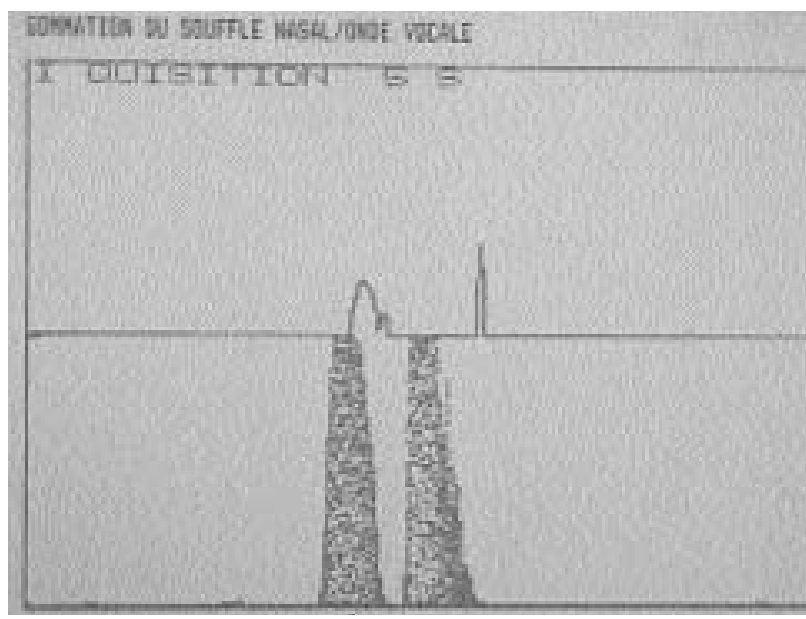

Figura 10. Registro preoperatorio. Significativa disminución del escape de aire y mejoramiento de la intensidad. (Fonemas: «I-U»). Figure 10. Post-operative registry. Significant decrease of air escape and improvement of intensity. Phonemas: "I-U".

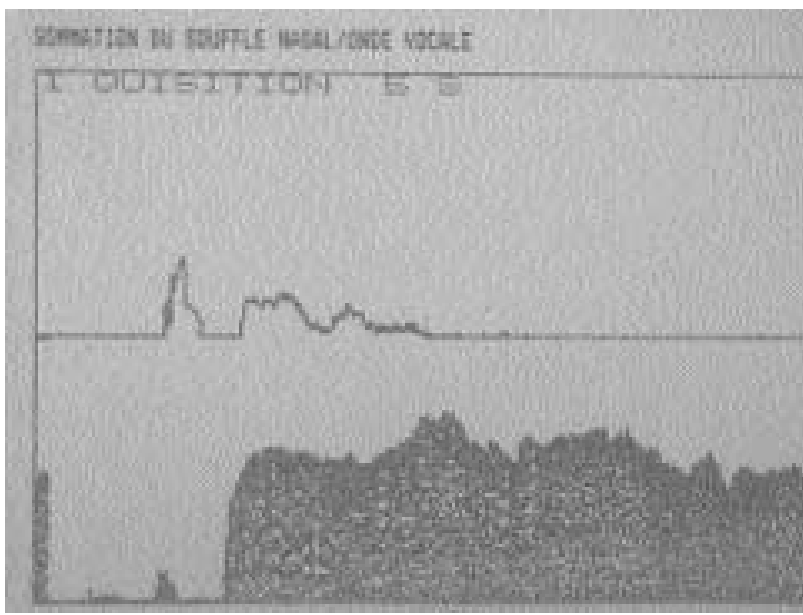

Figura 12. Registro preoperatorio. Mejoramiento notable en la intensidad. (Fonema: «IIIIIIII» vocal prolongada).

Figure 12. Post-operative registry. Noticeable improvement in intensity. Phonema: "IIIIII" (prolonged vowel). 


\section{Discusión}

La insuficiencia velofaríngea es una condición habitual de observar en nacidos con fisuras del velo del paladar y tratados quirúrgicamente, independiente de la técnica utilizada. Aunque existen antecedentes que confirman que una reconstrucción velar precoz está asociada a mejores resultados a largo plazo respecto de la calidad de la voz y la audición, 6-8 la insuficiencia velofaríngea puede presentarse como una secuela de cualquier técnica. Entre los factores a considerar en su aparición no sólo contarían, por lo tanto, factores dependientes del tratamiento realizado, sino que también a factores constitucionales, tales como el ancho y la profundidad de la faringe y la calidad de los tejidos involucrados, entre otros.

Para el tratamiento de la insuficiencia velofaríngea se ha ensayado diversos tratamientos, como por ejemplo la reeducación fonoaudiológica, que en realidad constituye la base de cualquier terapia, por si misma o como complemento a otro procedimiento. Se ha ensayado la utilización de órtesis u otro aditamento protésico que ayude a mejorar la competencia velofaríngea y las técnicas quirúrgicas, como la reoperación del velo o las técnicas de faringoplastias.

Es esta última quizás la técnica quirúrgica utilizada por el mayor número de cirujanos que se ocupan del manejo y tratamiento de esta condición.

Desde un punto de vista práctico, sin embargo, si comparamos las técnicas quirúrgicas de faringoplastias versus la de reconstrucción funcional secundaria del velo propuesta, veremos como la reoperación velar ofrece ciertas ventajas respecto la primera, dadas especialmente por su simplicidad quirúrgica.

En efecto, realizar una RF2V implica además de la reducción del tiempo operatorio, una economía en los medios necesarios para la obtención del objetivo: el alargamiento velar funcional. Este alargamiento ántero-posterior es conseguido al liberar la aponeurosis palatina con sus músculos tensor y elevador del velo desde sus inserciones en la bóveda palatina y una vez disecados, llevados a una posición más posterior, preservando estructuras fundamentales para su movilidad, tales como los ganchos pterigoideos.

Si se comparan ambas técnicas quirúrgicas en cuanto al territorio anatómico intervenido, vemos que en la reconstrucción secundaria, el sitio operatorio es el paladar y las incisiones las realizamos en la región velar o maxilar exclusivamente, sin extendernos a sectores anatómicos vecinos.

Inversamente, al comprometer las faringoplastias otros territorios topográficos, como la pared posterior o laterales de la faringe, ricas en vasos, como los vasos faríngeos, ascendentes y descendentes, existe el riesgo potencial de sangrado excesivo y con mayor razón en los casos que presentan variaciones anatómicas, como por ejemplo el Síndrome de Shprintzen o Síndrome Velocardiofacial, que en una RF2V no se presenta por poseer esta última un sustrato anatómico diferente.

En el período postoperatorio inmediato, las molestias originadas por la exposición y manipulación de los tejidos faríngeos determinados por las técnicas de faringoplastias son obviados al realizar una técnica de Reconstrucción funcional secundaria de velo (RF2V) por la misma razón detallada en el punto anterior. Este período se instrumental evaluation using an aerophonoscope. Both this evaluation and the phonoaudiological examination were performed in the preoperative as well as postoperative period of each patient. The aerophonoscopic studies were performed with an apparatus " "and the operation was done by the same phonoaudiologist in all the cases.

\section{Results}

Figures 1 to 6 show the aerophonoscopic registries referring to the prolonged, pretreatment and postsurgical phonemas "CHI - LLA", "I", " $U$ ", and "I" of the case illustrated.

In the upper half of the figure, an improper air escape through the nose due to failure in the occlusion of the velar sphincter can be seen and the intensity of the phoneme emission can be seen in the lower half. We can verify how, after the surgical correction, the air escape is almost imperceptible and the intensity of the voice increases considerably.

\section{Discussion}

Valopharyngeal insufficiency is a usual condition observed in those born with soft palate fissures and treated surgical$l y$, regardless of the technique used. Although there are clinical backgrounds that verify that an early velum reconstruction is associated to better long term results regarding the quality of voice and audition, ${ }^{6-8}$ velopharyngeal insufficiency may occur as a sequel of any technique. Treatment dependent factors would thus not only be important among the factors to be considered in its appearance, but also constitutional factors, such as width and depth of the pharynx and quality of the tissues involved, among others.

For the treatment of velopharyngeal insufficiency, several treatments have been tested, as, for example, phonoaudiological reeducation, which is really the base of any ther$a p y$, by itself, or as a complement to another procedure. The use or orthesis or other prosthesic additions that help to improve the velopharyngeal competence and surgical techniques, as the reoperation of the velum or the pharyngoplasty techniques, have been tested.

The latter may be the surgical technique used by the greatest number of surgeon who deal with the management and treatment of this condition.

From a practical point of view, however, if we compare the pharyngoplasty surgical techniques versus the secondary functional reconstruction of the velum proposed, we see how the velar reoperation offers certain advantages regarding the former, especially because of its surgical simplicity.

In fact, performing a secondary functional veloplasty not only implies reduction of the operative time but also economy in the means necessary to obtain the objective: functional velar lengthening. This antero-posterior lengthening is achieved on freeing the palatine aponeurosis with its tensor muscles and elevator of the soft palate from its insertions in the palate vault and once dissected, this is carried to a 
hace más llevadero, traduciéndose no sólo en menor dificultad para respirar, ya que no hay ningún tipo de restricción al paso del aire, sino que menores restricciones para alimentarse o hablar, ya que no existen zona cruentas expuestas, como sí sucede por el contrario en el postoperatorio de las faringoplastias.

Al analizar los mecanismo por el cual una y otra técnica mejoran la insuficiencia velo faríngea, veremos que éstos son completamente diferentes. Mientras la veloplastia secundaria mejora las condiciones morfofuncionales para obtener una competencia velofaríngea «normal» o «fisiológica» es decir, de forma activa, debida a una función muscular contráctil recuperada, la competencia velofaríngea que se obtiene después de una faringoplastia es en la mayor parte de los casos pasiva, por simple bloqueo mecánico del flujo aéreo hacia la cavidad nasal.

Desde el punto de vista funcional, una faringoplastia produce cambios de diversa índole. Por una parte es capaz de tratar la insuficiencia velofaríngea mejorando la voz, aspecto en el cual existe cierta unanimidad, ${ }^{9}$ ya que un colgajo desplazado desde la pared de la faringe impide mecánicamente el paso de aire a las fosas nasales. Sin embargo esta característica beneficiosa es también el origen de su mayor inconveniente: El bloqueo del paso del aire desde las fosas nasales, que puede resultar en una disminución importante del volumen de aire que debe pasar desde las fosas nasales a los pulmones. Si bien ha habido esfuerzos por mejorar los aspectos ventilatorios asociados a las técnicas de faringoplastias, ${ }^{10}$ existe evidencia documentada de obstrucción de la vía aérea a consecuencia de tratamientos quirúrgicos que utilizan el lumen de la faringe, como la misma técnica de Furlow, 2,11,12 aparición de trastornos cardiovasculares e incluso muerte postoperatoria en pacientes portadores de síndromes como el Velocardiofacial o una A. de Pierre Robin. ${ }^{13,14}$

Hasta hace poco, los ronquidos no eran considerados como un signo clínico patológico y la Medicina del Sueño aún no aparecía en el espectro de las disciplinas clínicas. Hoy, sin embargo, sabemos que el ronquido durante el sueño constituye un signo clínico que puede ser relevante dentro de la patología obstructiva del sueño y que las enfermedades del sueño tienen una elevada prevalencia en la sociedad, llegando en países desarrollados a afectar según algunos cálculos, entre un 5\% y un $10 \%$ de la población. ${ }^{15-18}$ Estas enfermedades generan deterioro en la calidad de vida, trastornos en la memoria y en la concentración y por ende del aprendizaje, complicaciones cardiovasculares, incrementan el número de accidentes de tráfico e influyen de modo importante en los accidentes laborales. Por otra parte, en relación a las características estructurales frecuentes de observar en los pacientes fisurados, están las deformidades del esqueleto facial. Debemos recordar, que la más frecuentemente observada es la falta de avance sagital y de descenso del maxilar superior y una menor longitud sagital de este mismo maxilar, considerada ya sea, como característica propia de la base maxilar y craneana de esta población, ${ }^{19}$ o simplemente a secuelas de técnicas quirúrgicas de cierre velar y/o maxilar no funcionales.20,21 Esto en la práctica significa que un número importante de pacientes fisurados presentan una deformidad dentofacial clase III con mordida invertida por retrognatia maxilar. Sabemos que una retrognatia, cualquiera sea su origen, constituye un factor more posterior position, preserving the essential structures for its mobility, such as the pterygoid hooks.

If both surgical techniques are compared in regards to anatomic territory operated, we see that the operative site in the secondary reconstruction is the palate and the incisions are performed in the velar or maxillary area exclusive$l y$, without going into neighboring anatomic sectors.

On the contrary, when other topographic territories such as the posterior or lateral wall of the pharynx, rich in vessels such as ascending and descending pharyngeal vessels are affected by the pharyngoplasties, there is a potential risk of excessive bleeding and even more so in the cases that present anatomic variations, as for example, the Shprintzen Syndrome or Velocardiofacial Syndrome, that does not occur in secondary functional veloplasty since it has a different anatomic substrate.

In the immediate postoperative period, the discomfort caused by the exposure and manipulation of the pharyngeal tissues determined by the pharyngoplasty techniques are obviated when a secondary functional veloplasty is performed for the same reason detailed in the previous point. This period is easier, there not only being less breathing difficulty, since there is no type of airway restriction, but also fewer eating and speaking restrictions, since there are no invasive zones exposed, as occurs, on the contrary, in the postoperative of the pharyngoplasties.

When the mechanisms by which one technique and another improve the velopharyngeal insufficiency are analyzed, we see that these are completely different. While the secondary veloplasty improves the morphofunctional conditions to obtain a "normal" or "physiological" velopharyngeal competence, that is, active, due to a recovered contractile muscular function, the velopharyngeal competence obtained after a pharyngoplasty is passive in most of the cases, due to simple mechanical blockade of the airflow towards the nasal cavity.

From the functional point of view, a pharyngoplasty produces different changes. On the one hand, it can treat the velopharyngeal insufficiency, improving the voice, an aspect that has some unanimity 9 since a flap shifted from the pharynx mechanically prevents air passage to the nasal pits. However, this beneficial characteristic is also the origin of its greatest disadvantage: blockage of the air passage from the nasal pits, that causes a significant decrease in the air volume that should pass from the nasal pits to the lungs. Although there have been efforts to improve the ventilatory aspects associated to the pharyngoplasty techniques, 10 there is documented evidence of airway obstruction due to surgical treatments that use the pharynx lumen, as the Furlow technique itself, 2,11,12 appearance of cardiovascular disorders and even post-operative death in patients having syndromes such as the Velocardiofacial or Pierre Robin ones. ${ }^{13,14}$

Until recently, snoring was not considered as a pathological clinical sign and Sleep Medicine had not appeared 
anatómico respiratorio adverso por reducción del espacio aéreo de la nasofaringe y/o por ubicación inadecuada de la lengua dentro de la cavidad bucal. En esta situación, el maxilar se encuentra ocupando un sitio anatómico más posterior y más alto en el piso superior de la cara, impactado en un área que normalmente debiera estar disponible para el paso del aire hacia los bronquios.

Resulta por lo tanto doblemente grave utilizar técnicas operatorias que lleven a restringir el paso del aire por la vía aérea superior y con ello facilitar la aparición de trastornos respiratorios obstructivos a una población que presenta características intrínsecas de riesgo obstructivo.

Precisamente la mayor ventaja de la técnica propuesta es devolver la morfología velar normal y con ello la capacidad a las estructuras velofaríngeas de obtener competencia, dejando este sector en condiciones de ser reeducado fonoaudiológicamente y así lograr una correcta voz libre de nasalizaciones, preservando el calibre y la funcionalidad de la vía aérea superior.

Tal vez el mayor inconveniente de esta técnica es su indicación limitada. Efectivamente no resulta útil en todos los casos de insuficiencia velofaríngea. Existen IVF de etiología neurológica, como ciertas parálisis velares u otras, idiopáticas, como algunas malformaciones que se expresan con agenesia o hipoplasia de sectores velopalatinos. Ellas no responden a un tratamiento quirúrgico como el propuesto ya que no se dispone del sustrato indispensable: El tejido muscular debidamente innervado, necesario para la contracción velar.

El desafío de la prevención y del tratamiento de la insuficiencia velofaríngea sigue vigente. Creemos que la búsqueda de soluciones a este antiguo problema debe orientarse hacia tratamientos en general y al diseño de técnicas quirúrgicas en particular que logren corregir la insuficiencia velofaríngea sin alterar otras estructuras, tales como la faringe, funciones, como la respiratoria o ritmos biológicos, como el circadiano.

En esta línea reflexiva, nuestra propuesta está orientada a la recuperación de la formas y de la función, buscando con nuestra técnica la recuperación de la anatomía y fisiología normal de la zona.

\section{Conclusiones}

- En casos seleccionados una Reconstrucción Funcional Secundaria Velo Palatina mejora la competencia velofaríngea.

- En esos casos, esta mejoría es evidenciable por medio de una aerofonoscopia.

- Esta corrección velofaríngea preserva el espacio respiratorio superior.

\section{Bibliografía}

1. Sloan G. Posterior pharyngeal flap and sphincter pharyngoplasty: The state of the art. Cleft Palate. Craniofa J 2000;37:2112-22.

2. Liao YF, Chuang ML, Chen PK, Chen NH, Yun C, Huang CS.Incidence and severity of obstructive sleep apnea following pharyngeal flap surgery in patients with cleft palate. Cleft Palate Craniofac / 2002;39:312-6. in the clinical discipline spectrum. Nowadays, however, we know that snoring during sleep is a clinical sign that may be relevant within the sleep obstructive disease and that sleep diseases have a high prevalence in society, affecting between $5 \%$ to $10 \%$ of the populations according to some calculations in developed countries. 15-18 These diseases generate deterioration in quality of life, memory and concentration disorders and therefore learning disorders, cardiovascular complications, increase the number of traffic accidents and significantly influence work accidents. On the other hand, there are deformities in the facial skeleton in relationship to the frequent structural characteristics observed in cleft patients. We should remember that the most frequently observed is the lack of saggital advance and decrease of superior maxillary and a lower saggital length of this same maxillary, whether considered as a characteristics of the maxillary and cranial base of this population ${ }^{19}$ or simply sequels of surgical techniques of non-functional velar and/or maxillary closure.20,21 In practice, this means that an important number of cleft patients present class III dentofacial deformity with inverted bite due to maxillary retrognathia. We know that a retrognathia, whatever its origin, is an adverse respiratory anatomical factor due to reduction of air space of the nasopharynx and/or due to inadequate location of the tongue within the buccal cavity. In this situation, the maxillary occupies a more posterior and higher anatomic site in the upper floor of the face, impacted in an area that normally should be available for air passage towards the bronchi.

Thus, it is doubly serious to use operative techniques that restrict the air passage by the upper airway and thus facilitate the appearance of obstructive respiratory disorders to a population that presents intrinsic characteristics of obstructive risk.

The greatest advantage of the technique proposed is precisely that it returns the normal velar morphology and thus the capacity to the velopharyngeal structures to obtain competence, leaving this sector in conditions of being reeducated phonoaudiologically and thus achieving a correct voice free of nasalizations, preserving the caliber and functionality of the upper airway.

Perhaps the greatest disadvantage of this technique is its limited indication. In fact, it is not useful in all the cases of velopharyingeal insufficiency (VFI). There is VFI having neurological etiology, as certain velar paralysis or others idiopathic ones, such as some malformations that are expressed with agenesis or hypoplasy of the velopalatine sectors. They do not respond to surgical treatment as that proposed since the indispensable substrate is not available: the duly innervated muscle tissue, necessary for velar contraction.

The challenge of the prevention and treatment of velopharyngeal insufficiency continues to exist. We believe that the search for solutions to this old problem should be oriented towards treatments in general and to the design of surgical techniques in particular that manage to correct velopharyngeal insufficiency without altering other struc- 
3. Puertas Cuesta FJ. El síndrome de aumento de resistencia de la vía aérea superior. Vigilia-Sueño 2000;12:S57-S64.

4. Cortés J. Secondary funtional repair of the velar cleft. A non-obstructive approach in velopharingeal incompetence». CLEFT 2002. Munich 2002.

5. Delaire J. Considérations sur la reconstitution de la luette et de la partie postérieure des palais congénitalement divisé. J Ann Chir Plast 1972;17:99-105.

6. Too-Chung M A. The assessment of middle ear function and hearing by tympanometry in children before and after early cleft palate repair. British Journal of Plastic Surgery 1983;36:295-9.

7. Psaume J. Brièveté de la période d'acquisition des phonèmes. Arguments pour le traitemente précoce des fentes maxillo-palatines. Rev Stomatol Chir Maxillofac 1992;93:349-50.

8. Paradise JL, Elster BA, Tan L. Evidence in infants with cleft palate that breast milk protects against otitis media. Pediatrics 1994;94:853-60.

9. Huang MH, Riski JE, Cohen SR, Simms CA, Burstein FD. An anatomic evaluation of the furlow double opposing Z-plasty technique of cleft palate repair. Ann Acad Med Singapore 1999;28:672-6.

10. Hogan VM. A clarification of the surgical goals in cleft palate speech and the introduction of the lateral port control (I.p.c.) pharyngeal flap. Cleft Palate J 1973;10:331-45.

11. Yu-Fang Liao, Yun $C$, Chiung-Shing $H$, Chen PKT, Ning-Hung C, Kai-Fong $H$, Ming-Lung Chuang. Longitudinal Follow-Up of Obstructive Sleep Apnea Following Furlow Palatoplasty in Children With Cleft Palate: A Preliminary Report. The Cleft Palate-Craniofacial Journal 2003;40.

12. Robson MC, Stankiewicz JA, Mendelsohn JS. Cor pulmonale secondary to cleft palate repair. Plast Reconstr Surg 1977; 59:754-7.

13. Kravath RE, Pollak CP, Borowiecki B, Weitzman ED. Obstructive sleep apnea and deathassociated with surgical correction of velopharyngeal incompetence. The Journal of Pediatrics 1980;96:645:8.

14. Jackson P, Whitaker LA, Randall P. Airway hazards associated with pharyngeal flaps in patients who have the Pierre Robin syndrome. Plast Reconstr Surg 1976; 58:184-6.

15. Lugaresi E, Zucconi M, Bixler EO. Epidemiology of sleep disorders. Psychiatric Annals 1987; 17:446-53.

16. Marín JM, Gascón JM, Carrizo S, Gispert J. Prevalence of sleep apnoea syndrome in the Spanish adult population. Int J Epidemiol 1997;26:381-6.

17. Bixler EO, Kales A, Soldatos Cr, Kales JD, Healey S. Prevalence of Sleep Disorders in the Los Angeles Metropolitan Area. Am J Psych 1979;136:1257-62.

18. Vela-Bueno A. de Iceta M. Fernández C. Prevalencia de los trastornos del sueño en la ciudad de Madrid. Gaceta Sanitaria 1999;13:441-8.

19. Granic X. Análisis arquitectural y estructural de la base craneal anterior en sujetos fisurados labio-maxilo-palatinos. Tesis, Facultad de Odontología. Universidad de Chile 2002.

20. Joos, U. Skeletal growth after muscular reconstruction for cleft lip, alveolous and palate. Br J Oral Maxillofac Surg 1995;33:139-44.

21. Markus AF, Precious DS. Effect of primary surgery for cleft lip and palate on midfacial growth. Br J Oral Maxillofac Surg 1997;35:6-10. tures, such as the pharynx, functions, such as respiratory or biological rhythms, such as circadian.

Along this reflexive line, our proposal is oriented to the recovery of the forms and function, searching for the recovery of normal anatomy and physiology of the zone with our technique.

\section{Conclusions}

- In selected cases, Secondary Functional Veloplasty improves velopharyngeal competence.

- In these cases, this improvement is seen by means of an aerophonoscope.

- This velopharyngeal correction preserves the upper respiratory space. 


\title{
Veloplastia funcional secundaria: una alternativa no obstructiva en el tratamiento de la insuficiencia velofaríngea
}

\author{
Secondary functional veloplasty: a non-obstructive approach to valopharyngeal insufficiency
}

El artículo "Veloplastia funcional secundaria" revisa los resultados de 15 veloplastias secundarios según Delaire en el tratamiento de insuficiencia velofaríngea. Las edades de los pacientes variaban entre 8 y 22 años. Los criterios de inclusión abarcaron pacientes con un acortamiento velar y con suficiente masa muscular.

El propósito de cualquier cirugía en la faringe de pacientes fisurados para mejorar el habla es para reducir emisión de aire nasal, susurro nasal y rinolalias. Los autores dicen que una velofaringoplastia con colgajo posterior cierra la vía aérea nasofaríngea estáticamente y puede producir apnea obstructiva del sueño. Uno puede preguntarse si el alargamiento velar, tal como está propuesto por los autores, puede llegar a una condición similar. Después de todo, a más edad, la reconstrucción de un esfínter dinámico se están haciendo cada vez más una ilusión y sólo se están obteniendo resultados del alargamiento estático (u obstrucción).

Las indicaciones de los autores son un velo corto con adecuado volumen muscular. Los autores no indican cómo diagnostican el volumen muscular. Puede ser insuficiente la inspección clínica, bien intraoral o con nasoendoscopia. La resonancia magnética sería una posibilidad. La próxima cuestión está relacionada con la técnica quirúrgica. Los autores describen incisiones de línea media, suturando todas las capas. Inevitablemente, esto puede producir una contracción de la cicatriz sagital, con acortamiento secundario del velo. Alternativamente, una palatoplastia secundaria de Furlow puede evitar estas contracciones, ${ }^{1}$ y los dos casos que he tratado de esta manera han resultado en mejora del habla, tal como estaba observado por la logopeda. Es verdad que los niños tenían una edad inferior a 6 años.

Desde luego, uno puede cuestionar la indicación en cuanto a la edad. Pacientes entre 8 y 22 años no se consideran normalmente sensibles a la cirugía del colgajo posterior. ${ }^{2}$ Hay que felicitar a los autores por los buenos resultados obtenidos con la reconstrucción de la hamaca muscular en este grupo de edad.

Finalmente, las fisuras del velo del paladar primariamente tratadas con la técnica de Von Langenbeck, sin veloplastia intravelar, son bastante raras en el cuidado contemporáneo de las fisuras.

M. Mommaerts

FEBOMS, FICS, Director Cleft Palate \& Craniofacial. Center Brugge, Belgium
The article "Veloplastia funcional secundaria" reviews the results of 15 secondary veloplasties acc. to Delaire in the treatment of velopharyngeal insufficiency. The patients were between 8 and 22 years of age. Inclusion criteria comprised patients with a short velum and with sufficient muscle bulk.

The purpose of any speech improving surgery in the phar$y n x$ of cleft patients, is to reduce nasal air emission, nasal rustle and hypernasality. The authors state that a velopharyngoplasty with posterior flap closes the nasopharyngeal airway in a static way and may cause obstructive sleep apnea. One may wonder if velar lengthening, such as proposed by the authors, may not result in a similar condition. After all, with increasing age, the reconstruction of a dynamic sphincter is becoming more and more an illusion, and results are being obtained from static lengthening (or obstruction) only.

Authors' indications are a short velum with adequate muscle volume. The authors do not indicate how they diagnose the muscle volume. Clinical inspection, intra-orally or with nasendoscopy, may be insufficient. Magnetic resonance imaging would be a possibility.

The next issue concerns the surgical technique. The authors describe midline incisions and suturing of all layers. Inevitably, this may lead to sagittal scar contraction, with secondary shortening of the velum. Alternatively, a secondary Furlow palatoplasty might avoid these contractions ${ }^{1}$ and the two cases I have treated this way, also ended up with an improvement of speech as appreciated by the speech therapist. I admit that the children were younger than 6 years.

Indeed, one may question the indication regarding age. patients between 8 and 22 years are normally not considered to be sensitive to posterior flap surgery. ${ }^{2}$ The authors are to be congratulated with the good results they obtained with muscular sling reconstruction in this age group.

Finally, soft palate clefts primary treated with the Von Langenbeck technique, without intravelar veloplasty, are rather exceptions in contemporary cleft care.

\section{Bibliografía}

1. Mommaerts MY, Kablan F, Sheth S, Laster Z. Early maxillary growth in complete cleft lip, alveolus and palate patients following Widmaier-Perko's, or a modified Furlow's technique of soft palate repair. J Cranio Maxillofac Surg 2003;31:209.

2. Meek MF, Coert JH, Hofer SO, Goorhuis-Brouwer SM, Nicolai JP. Short-term and long-term results of speech improvement after surgery for velopharyngeal insufficiency with pharyngeal flaps in patients younger and older than 6 years old: 10-year experience. Ann Plast Surg 2003;50:13. 